\title{
Do spiders respond to global change? A study on the phenology of ballooning spiders in Switzerland 1
}

\author{
Gilles BLANDENIER ${ }^{2}$, Odile T. BRUGGISSER \& Louis-Félix BERSIER, University of Fribourg, Unit of Ecology \\ \& Evolution, chemin du Musée 10, CH-1700 Fribourg, Switzerland, e-mail: g.blandenier@bluewin.ch
}

\begin{abstract}
We studied ballooning spiders captured weekly over an 11-y period using a 12.2-m-high suction trap in an agricultural landscape of western Switzerland. We analyzed population trends, changes in phenology, and species composition. Yearly trends in population size of the most abundant species were studied with nonparametric correlations. We found that these trends were markedly different for ground-living ( $92 \%$ of all decreasing species) and upper-strata species ( $75 \%$ of all increasing species). These contrasting tendencies can be explained by a stronger effect of meteorological conditions on species living at ground level and by an observed decrease in habitat availability for open-habitat species. The phenology of ballooning spiders was analyzed using mixtures of Gaussian curves fitted to the yearly capture data; this was possible for the 7 most abundant species. From these, we estimated the dates of the ballooning peaks for each species and each year (1 to 4 peaks depending on the species). We found that the dates remained mostly constant: the timing of dispersal peaks showed no annual trend for all but 1 species. Using nonparametric correlation, we analyzed the relationships between the dates of the peaks and the meteorological parameters occurring before the peak dates. In line with the absence of trend, the dates of the peaks were only weakly related to meteorological conditions. The extreme climatic event of 2003 had a strong impact by reducing populations of ground-living species. Using Canonical Correspondence Analysis and clustering methods, we identified a strong shift in the phenological structure of the ballooning spider assemblage in that year. In all, despite noticeable trends in population size during the study period, the dispersal phenology did not change, which contrasts with observations from other arthropod groups.

Keywords: ballooning, climate, dispersal, phenology, spiders, suction trap.
\end{abstract}

Résumé: Les araignées dont la dispersion se fait par voie aérienne («ballooning») ont été capturées par un piège à aspiration de 12,2 $\mathrm{m}$ de haut, toutes les semaines pendant 11 ans, dans une région agricole de Suisse romande. Nous avons étudié les tendances des populations, les changements de la phénologie et de la composition des assemblages d'espèces. Les tendances annuelles de la taille des populations des espèces les plus abondantes ont été analysées avec des corrélations non paramétriques. Nous avons trouvé une différence marquée entre espèces vivant au sol ( $92 \%$ de toutes les espèces qui ont diminué) et dans les strates supérieures ( $75 \%$ de toutes les espèces qui ont augmenté). Ces tendances contrastées peuvent être expliquées par un effet plus marqué des conditions météorologiques sur les espèces vivant au sol et par une diminution observée de la disponibilité des milieux ouverts. La phénologie des araignées dont la dispersion se fait par voie aérienne a été décrite par des mélanges de courbes gaussiennes ajustées aux données des captures annuelles; cette analyse a été possible pour les 7 espèces les plus abondantes. Ceci nous a permis d'estimer les dates des pics de dispersion pour chaque espèce et chaque année ( 1 à 4 pics selon l'espèce). Nous avons trouvé que ces dates restent dans l'ensemble constantes: à l'exception d'une espèce, aucune tendance annuelle n'a été décelée. À l'aide de corrélations non paramétriques, nous avons étudié les relations entre ces dates et les conditions météorologiques durant la période précédant les pics. En accord avec l'absence observée de tendances, les dates des pics ne sont que faiblement liées aux conditions météorologiques. L'année 2003 a connu un événement climatique extrême qui a provoqué une forte diminution des populations d'espèces vivant au sol. En utilisant des méthodes de groupement et une analyse canonique des correspondances, nous avons identifié un changement important de la structure phénologique de l'assemblage d'espèces pour cette année-là. Globalement, en dépit des tendances observées des tailles de population durant l'étude, la phénologie de dispersion aérienne des araignées est restée très stable, ce qui contraste avec les résultats obtenus avec d'autres groupes d'arthropodes.

Mots-clés : araignées, ballooning, climat, dispersion, phénologie, piège à aspiration.

Nomenclature: Platnick, 2013.

\section{Introduction}

Spiders are able to travel by air suspended with a silk thread that is used as a sail. This mode of passive dispersal, called ballooning, confers very efficient colonization abilities (Bell et al., 2005; Szymkowiak, Górski \& Bajerlein, 2007). According to Marc, Canard, and Ysnel (1999), dispersal in spiders is triggered by intrinsic factors at particular periods of the life cycle: juveniles in transition from gregarious to solitary phase, and adults during reproduction periods. Extrinsic factors also play a role, depending on either the abiotic environment, when habitat structure or microclimatic conditions change, or the biotic environment, when competition for food or nesting places becomes too high.

Dispersal ability of different species has been shown to depend on habitat preferences and landscape structure (Bonte et al., 2003; 2006; Bonte, Hovestadt \& Poethke, 2010). For a given species, sources of individual variability 
in ballooning can come from perturbation of their habitat (Entling, Stämpfli \& Ovaskainen, 2011), thermal conditions during juvenile development (Bonte et al., 2008), genetic background (Bonte, Deblauwe \& Maelfait, 2003), inbreeding (Bonte, 2009), maternal effects (Mestre \& Bonte, 2012), presence of microbial endosymbionts (Goodacre et al., 2009), and information from congeners (De Meester \& Bonte, 2010).

Regardless of the reason for its initiation, ballooning can occur only if meteorological conditions are suitable (Reynolds, Bohan \& Bell, 2007). In Germany, Rensch, Volkmar, and Spilke (2010) showed that many meteorological parameters (air pressure, wind direction, mean temperature $20 \mathrm{~cm}$ underground, sun radiation, rain sum) influenced the number of spiders caught in a suction trap (Taylor \& Palmer, 1972). They also found that the number of captures on a given day was dependent on temperature (mean at ground level and $20 \mathrm{~cm}$ underground), humidity, and mean wind speed and direction measured on the previous day. Intriguingly, higher relative humidity led to higher spider counts, which they interpreted as the consequence of heavier silk thread and of condensation on the body that render spiders more prone to be captured. Rensch et al. (2010) also found that the response to meteorological conditions differed among families. Using the same data set as analyzed here but considering all spiders together, Bruggisser (2010) also pointed out the influence of meteorological parameters: ballooning spiders responded positively to temperature and global radiation, and, in contrast to the response seen by Rensch, Volkmar, and Spilke (2010), negatively to humidity. Birkhofer and Wolters (2012) showed that climatic conditions also alter spider community composition and the functional role of these important predators.

Given the observed link with meteorological conditions, phenological patterns of ballooning spiders would be expected to have changed in recent years, following the current climatic changes (CH2011, 2011). Phenological changes have indeed been reported in many other groups, including vertebrates, plants, and insects (Parmesan \& Yohe, 2003; Root et al., 2003; Parmesan, 2007). For example, in high-arctic Greenland, the phenology of arthropods, including Linyphiid and Lycosid spiders, has advanced considerably during recent years (Høye \& Forchhammer, 2008). Here, the date of snowmelt is a good predictor for the phenology of most arthropods, and shortterm weather fluctuations play a weaker role.

There are very few long-term phenological data sets for spiders in central Europe, and such information is needed to understand the effect of global change on these important predators. Using an original data set of ballooning spiders captured during 11 y in western Switzerland, we explore the trends in population sizes, the relationships between timing of ballooning and meteorological conditions, and the structure of the assemblage of ballooning species. We hypothesize that the annual timing of aerial dispersal in spiders will vary according to meteorological parameters, especially temperature. We also predict that the trends in yearly abundances will reflect changes in both meteorological conditions and habitat availability.

\section{Methods}

\section{STUDY SITE}

Ballooning spiders were collected at a height of $12.2 \mathrm{~m}$ using a Rothamsted Insect Survey suction trap (Taylor \& Palmer, 1972; Derron \& Goy, 1987) between 1994 and 2004. The trap was located in the western region of the Swiss Plateau (in Changins, Canton of Vaud, $46^{\circ} 24^{\prime} 8^{\prime \prime} \mathrm{N}$, $6^{\circ} 14^{\prime} 0$ "E, $440 \mathrm{~m}$ AMSL; mean annual temperature: $10.8^{\circ} \mathrm{C}$; mean annual precipitation: $1091 \mathrm{~mm}$ during the study), at the Agroscope ACW Changins-Wädenswil research station.

The study area is a fragmented agricultural landscape, characterized by a predominance of agroecosystems but also buildings and associated infrastructure and forests (for more details, see Blandenier, 2009). We considered the data for all municipalities located in a radius of $5 \mathrm{~km}$ around the suction trap and excluded lakes in the computation of surface areas (data from www.bfs.admin.ch/bfs/portal/fr/index/ themen/02/03/blank/data/gemeindedaten.html; accessed on July 2009). Changes in habitat availability due to human activity occurred in the study region during the study period (Bruggisser, 2010). Between 1992 and 2004, agricultural land use decreased by 3\% (1992: $30.5 \mathrm{~km}^{2} ; 2004: 29.6 \mathrm{~km}^{2}$ ) and was replaced mostly with buildings and associated infrastructure, which increased by $7 \%\left(1992: 11.3 \mathrm{~km}^{2}\right.$; 2004: $\left.12.1 \mathrm{~km}^{2}\right)$; forest cover $\left(3.6 \mathrm{~km}^{2}\right)$ did not change.

\section{SAMPLING OF SPIDERS}

Data were collated weekly for 11 y, from 16 April 1994 until 31 December 2004. The trapping was stopped during the first 2 winters of the survey (17 December 1994 17 March 1995 and 3 December 1995 - 17 March 1996) and at the beginning of 1998 for maintenance (12 February - 21 April). In order to compare the annual captures, we replaced the missing data (weeks without trapping) with the mean abundance for that week during the sampled years (this represents 150 additional observations).

Adult spiders were determined to species, and immatures only to family or genus level if possible, except in 10 cases where it was possible to go to species level (Heimer \& Nentwig, 1991; Roberts, 1993; Nentwig et al., 2010). We captured 15398 spiders from 16 families and 103 taxa. The list of taxa can be found in Blandenier (2009), and the ecological classification of the species is based on Hänggi, Stöckli, and Nentwig (1995).

\section{Meteorological DATA}

Meteorological parameters were measured daily $300 \mathrm{~m}$ southwest from the suction trap by the meteorological station of Changins (Meteoswiss). The measured parameters were minimal, maximal, and average temperature at $2 \mathrm{~m}$ above ground; minimal temperature $5 \mathrm{~cm}$ above ground (all temperatures in $\left.{ }^{\circ} \mathrm{C}\right)$; average relative humidity $(\%)$; sum of precipitation $(\mathrm{mm})$; and global radiation $\left(\mathrm{MJ} \cdot \mathrm{m}^{2}\right)$. Wind measurements were made on a mast at $12.2 \mathrm{~m}$ height, $10 \mathrm{~m}$ northwest of the suction trap. To match the temporal resolution of spider sampling, all meteorological data were averaged for each week; coefficients of variation (\%) were also computed on a weekly basis.

Meteorological conditions were extreme in the year 2003: for 82 of the $365 \mathrm{~d}$, average temperature 
exceeded $20{ }^{\circ} \mathrm{C}$ (average between 1994 and 2004 without 2003: $37.6 \mathrm{~d} \pm 7.8 \mathrm{SD}$ ); global radiation was greater than $20 \mathrm{MJ} \cdot \mathrm{m}^{2}$ for $97 \mathrm{~d}$ (average: $76.3 \mathrm{~d} \pm 7.1 \mathrm{SD}$ ); humidity was above $80 \%$ for only $82 \mathrm{~d}$ (average: $117.6 \mathrm{~d} \pm 14.2 \mathrm{SD}$ ); and during the summer months (June to August), $65 \mathrm{~d}$ were observed without precipitation (average: $54 \mathrm{~d} \pm 4.5 \mathrm{SD}$ ) (Bruggisser, 2010). In contrast, fall 2003 was colder than the mean. To avoid possible bias due to this extreme event, we analyzed both the full data set from 1994 to 2004 and a restricted data set from 1994 to 2002.

\section{DESCRIPTION OF PHENOLOGY}

The phenology of ballooning of the 7 most abundant species (with at least 200 individuals captured) was described firstly by identifying the number of activity periods with a so-called bump-hunting method (Good \& Gaskins, 1980; Silverman, 1981), which tests for significant peaks, in the summed weekly abundances over the 11 y (see Blandenier et al., 2013 for details of the method). Then, for each year, we described each activity period (i) of ballooning by its peak and spread. The former is the mean ( $m_{i}$ [days]) of a Gaussian curve fitted to the weekly abundance data for that period; the latter the standard deviation $\left(s_{i}[\right.$ days] $)$ of this curve. For this purpose, for each considered taxon and year, we fitted a mixture of Gaussian curves to the weekly abundance data $y$ :

$$
\hat{y}=\sum_{i=1}^{k} w_{i} \cdot N\left(m_{i}, s_{i}^{2}\right)
$$

with $\hat{y}$ being the estimated abundance, $k$ the number of activity periods $(k=1,2,3$, or 4$)$ given by the bumphunting method, and $w_{i}$ the weight of each activity period $\left(\Sigma w_{i}=1\right)$. We used a maximum likelihood method for the estimation of parameters.

\section{YEARLY PHENOLOGICAL TRENDS IN SPIDER ASSEMBLAGES}

We described the phenological ballooning structure for the assemblage consisting of the 10 adult species that were observed every year during the study period. To detect trends, we used a Canonical Correspondence Analysis (CCA; Legendre \& Legendre, 1998) with year as explanatory variable. The rows of the response matrix contain the 10 species in each year (110 observations) and the columns the number of captures in each of the 52 weeks (transformed into percentages to give the same weight to each observation). The variable year was considered as a factor and represented as centre of gravity in the ordination biplot (Borcard, Gillet \& Legendre, 2011). We tested the significance of the variable year with a permutation test, using the functions cca and anova of the vegan package (Oksanen et al., 2009) in R (R Development Core Team, 2009). Additionally, we tested each year against all others pooled to detect which one was the most different in terms of phenological structure.

To further explore the phenological ballooning structure of the spider assemblage in each year, we used a clustering method (complete-linkage agglomerative) on the $\mathrm{X} 2$ distances between species described by their weekly abundances. We obtained a dendrogram for each year, enabling comparison of species groups described by their similarity in ballooning phenology. We used the function clust in the vegan package in $\mathrm{R}$. We then applied a permutation test to identify statistically significant groups according to the procedure of Jaksić and Medel (1990).

\section{STATISTICAL ANALYSES}

For each taxon, we used non-parametric Spearman correlation to analyze the trends in yearly total abundance (abundances correlated with year). For the 7 most abundant species, we also used Spearman correlation to analyze 1) the trends in the dates of the ballooning peaks (correlated with year) and 2) the relationships between dates of peaks and meteorological conditions in each year. Following the approach of growing degree-day (Neuheimer \& Taggart, 2007), we considered meteorological conditions occurring before the peaks. For each meteorological parameter, we computed the mean in daily data during the month preceding each peak.

We used a binomial test to compare the number of decreasing versus increasing taxa, and a $G$-test of independence (Sokal \& Rohlf, 2000) to compare the numbers of decreasing versus increasing species for spiders living at ground versus upper-strata levels. We used a glm with binomial family to analyze the influence of Linyphiidae in these proportions.

\section{Results}

\section{ANNUAL SHIFTS IN SPIDER ABUNDANCES}

Between the years 1994 and 2004, simple non-parametric correlation analyses revealed that, among the 41 most abundant taxa, 26 decreased and 15 increased (binomial test, $P=0.12$; Appendix I, Table I); this ratio did not change with the restricted data set, which excludes the extreme year 2003 and the year 2004. Interestingly, 75\% of all increasing species live in the herb, shrub, and tree layers, and $92 \%$ of all decreasing species live at ground level ( $G$-test of independence: $G_{\text {adj }}=12.3, P<0.001$; the test remained significant at $P=0.022$ with the restricted data set). Note that the Linyphiidae family is the most affected, as all but 1 species are epigeal; however, while the difference in population trends is partly driven by this family, it is only significant for ground-dweller versus higher-strata taxa (binomial glm with increasing or decreasing trend as response variable: $P=0.10$ with Linyphiidae versus non-Linyphiidae as explanatory variable; $P=0.018$ with ground-living versus non ground-living as explanatory variable; and $P=0.89$ and $P=0.096$, respectively, when both explanatory variables are included in the model). Based on the fitted values of a regression analysis, the overall abundance of captured individuals living at ground level decreased by $8 \%$ between 1994 and 2002. Between 1994 and 2004, 6 species showed a statistically significant decrease and 4 a significant increase; the former were all ground-living species, while the latter were composed of 1 ground-living and 3 upper-strata species (Appendix I, Table I). Two species illustrate these different trends: captures of Araeoncus humilis decreased over the study period, with extremely 
low abundances in early summer and autumn of 2003 and 2004 (Appendix I, Figure 1). In contrast, Mermessus trilobatus, an introduced species, appeared during the year 1997 in our study area. This species showed a strong increasing trend, but its abundance also collapsed in late summer and autumn 2003 and 2004 (Appendix I, Figure 2). Like A. humilis and $M$. trilobatus, most other ground-living spiders decreased in the year 2003. Interestingly, no diminution of captures in 2003 and 2004 was detected for the spiders inhabiting herb, shrub, and tree layers. Nuctenea umbratica even showed an unusually high number of juveniles in 2003. During that year, we also captured unusually large adults of large-bodied araneid species like Aculepeira ceropegia and Araneus diadematus.

\section{SHIFTS IN BALLOONING PHENOLOGY DURING THE} STUDY PERIOD

For simplicity, we classified the peaks into 3 groups: later winter/spring (February to May), summer (June to September), and autumn (October and November). Inspection for shifts in ballooning peaks for the 7 most abundant species does not reveal consistent trends (Table I and Figure 1). The weights and the spreads of the peaks also do not show any trend, and are not discussed further. Only the timing of the autumn peak for Erigone dentipalpis shows a significant negative trend, indicating that it occurs later in the season (Table I). No overall trend is apparent for late-winter/spring and summer peaks, with 6 negative and 5 positive correlations, while all except 1 autumn peak tend to occur later.

The level of variability in the dates of the peaks differs among species (Figure 1). The timing of the peaks of A. humilis and Agyneta rurestris, both "trimodal" species, is quite constant during the study period. In A. humilis, the interval between the earliest and the latest first peak is $42 \mathrm{~d}$, the interval for the second peak is $29 \mathrm{~d}$, and that for the third peak is $20 \mathrm{~d}$. For $A$. rurestris, the same intervals are $16 \mathrm{~d}, 47 \mathrm{~d}$, and $18 \mathrm{~d}$, respectively. In 2003 the summer peak of these 2 species took place $20 \mathrm{~d}$ before the mean date in the other years. In A. humilis, the autumn activity period is the most important; in A. rurestris, the early summer peak is the most important.

The other 5 studied species show greater variability in the yearly timing of peaks. Mermessus trilobatus shows variation in its late summer peak, which again occurred earlier in 2003. The autumn activity period is regularly the most important in this species. In Tenuiphantes tenuis and Erigone atra, timing of all peaks is highly variable (the interval between the earliest and the latest first peak is 52 and $109 \mathrm{~d}$, and that for the second peak is 67 and $75 \mathrm{~d}$, respectively; for E. atra, the interval for the third peak is $61 \mathrm{~d}$ ); the early summer activity period of the latter species is almost always the most important, while there is no clear tendency in T. tenuis. The date of the spring peak of Porrhomma microphthalmum shows great variability, especially after 2000 , which contrasts with the more constant early summer activity period; the latter was almost always the most important. Erigone dentipalpis presents the greatest variability in the number and the weight of peaks, with 4 peaks detected in 2002 . The early summer and the autumn peaks are the most constant, while earlier in the season and in late summer the species show supplementary peaks during some years.

\section{LINK BETWEEN PEAKS AND METEOROLOGICAL PARAMETERS}

Examination of Appendix I, Table II reveals that the timing of the peaks shows little relationship to meteorological conditions in the preceding month for the 7 most abundant species, and that the sign of the relationships differs among species, except for the summer peak (note that the meteorological parameters are not independent, with positive correlations among the temperatures and radiation measures, themselves negatively linked to humidity). For the latter, the Spearman correlations with the 4 measures of temperature are negative for all but 1 species. The measures of temperature are the most important variables but, when all peaks are considered, are significant only for 2 species, A. humilis (Appendix I, Figure 3) and E. dentipalpis. Relative humidity is significantly correlated with the timing of peaks in E. atra. When considering which peak is the most influenced by meteorological parameters, we find that the summer peak yields the largest number of significant results; however, they again concern mostly A. humilis and E. dentipalpis. Peaks of $A$. humilis appear earlier if temperature and global radiation are high. A similar pattern is found for the summer peak of E. dentipalpis. For E. atra and T. tenuis, the autumn peak is delayed if temperature is high. In $P$. microphthalmum the spring peak tends to occur earlier when humidity is high and is delayed when radiation is high.

TABLE I. Trends in the date of peaks between 1994 and 2004 for the 7 most abundant species. Spearman correlations of year against peak date; boldface type: $P \leq 0.05$.

\begin{tabular}{|c|c|c|c|c|c|c|c|c|}
\hline & & Ara hum & Eri atr & Eri den & Agy rur & Mer tri & Por mic & Ten ten \\
\hline \multirow[t]{3}{*}{ Late-winter/spring peak } & Spearman & -0.109 & -0.482 & - & 0.412 & - & -0.476 & - \\
\hline & $n$ & 11 & 8 & - & 11 & - & 8 & - \\
\hline & $P$-value & 0.749 & 0.226 & - & 0.208 & - & 0.234 & - \\
\hline \multirow[t]{3}{*}{ Summer peak } & Spearman & 0.032 & 0.141 & -0.333 & 0.383 & -0.029 & -0.137 & 0.117 \\
\hline & & 11 & 11 & 9 & 11 & 6 & 11 & 9 \\
\hline & $P$-value & 0.926 & 0.679 & 0.381 & 0.245 & 0.957 & 0.689 & 0.765 \\
\hline \multirow[t]{3}{*}{ Autumn peak } & Spearman & -0.236 & -0.477 & -0.946 & -0.500 & 0.335 & -0.168 & -0.168 \\
\hline & $n$ & 11 & 9 & 9 & 10 & 8 & 9 & 8 \\
\hline & $P$-value & 0.484 & 0.194 & $<0.001$ & 0.141 & 0.417 & 0.666 & 0.691 \\
\hline
\end{tabular}

Species: Araeoncus humilis, Erigone atra, Erigone dentipalpis, Agyneta rurestris, Mermessus trilobatus, Porrhomma microphthalmum, Tenuiphantes tenuis. 

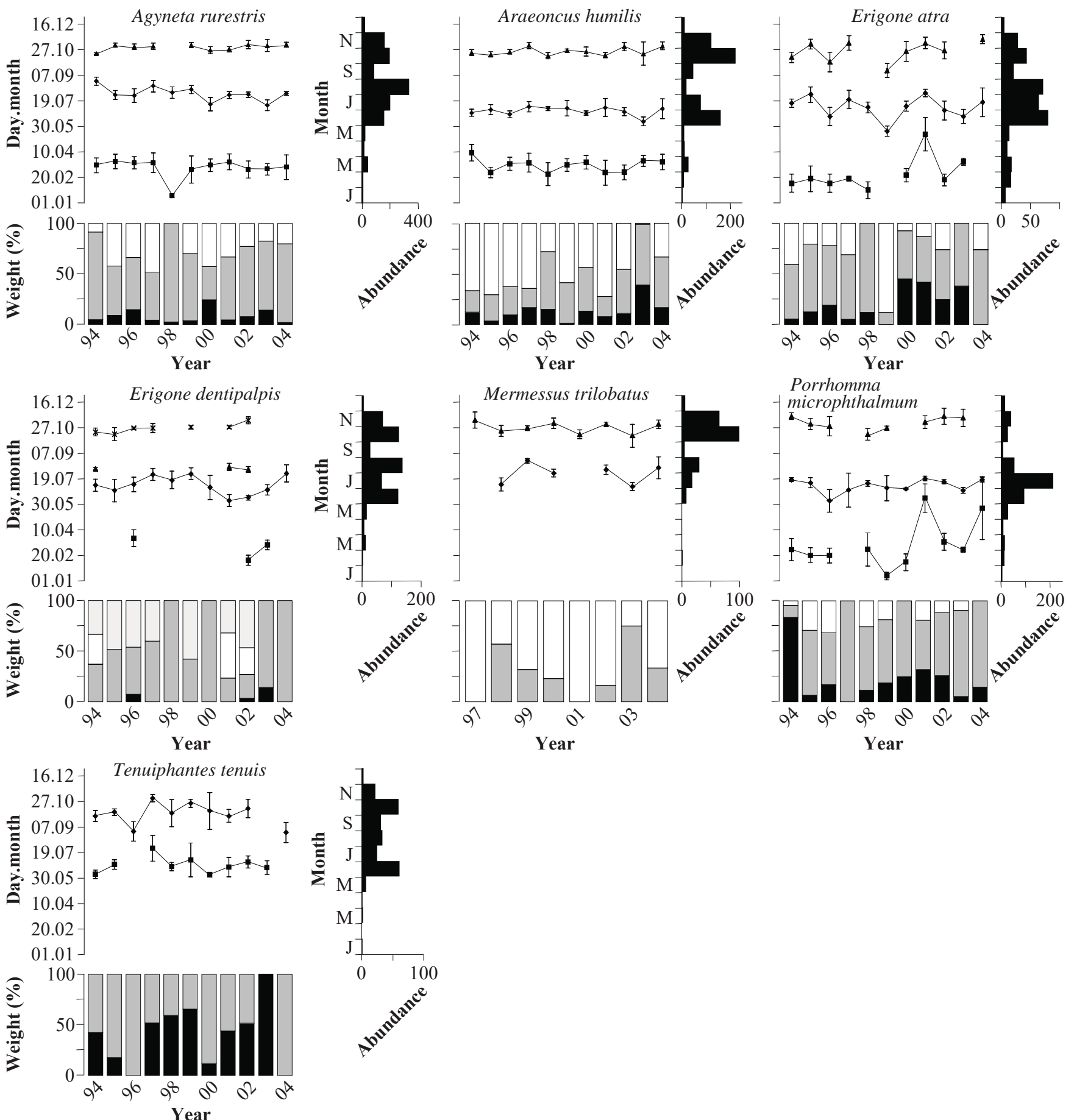

FIGURE 1. Ballooning peaks of the 7 most abundant species. 1) Upper panel: date of peaks with 95\% confidence interval. Square: first peak; diamond: second peak; triangle; third peak; cross: fourth peak. 2) Right panel: monthly abundance of captures (all years summed). 3) Lower panel: weight of the peaks. Black: first peak; dark grey: second peak; white: third peak; light grey: fourth peak.

YEARLY PHENOLOGICAL TRENDS IN SPIDER ASSEMBLAGES

The results of the CCA analysis are shown in Figure 2. The explanatory variable year accounts for $11 \%$ of the total variation and is significant (ANOVA test with $P=0.007$ based on a Monte Carlo test with 10000 permutations). Inspection of Figure 2 reveals that the centre of gravity of year 2003, when meteorological conditions were extreme during summer, is the most distant from other years.
This pattern is confirmed by the ANOVA test for 2003 against all other years pooled $(P=0.046)$. The year 1997 is also significantly different from all other years $(P=0.048)$, but this result is due to 1 species (Porrhomma oblitum), which is an outlier in that year.

When analyzing assemblage structure in each year with a cluster analysis (Appendix I, Figure 4), a separation between the 3 "uni" and 7 "multimodal" species is apparent. 


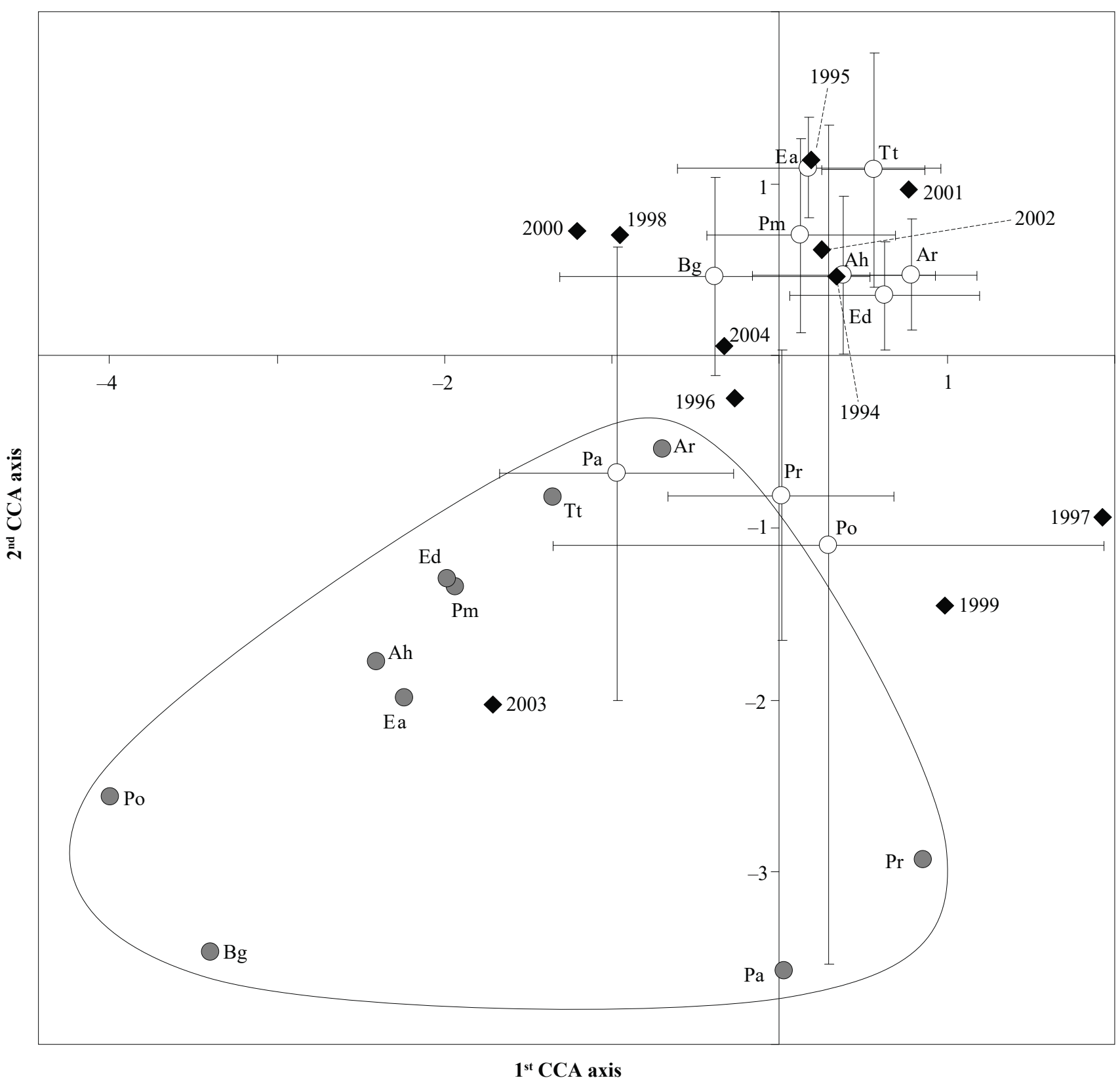

FIGURE 2. Canonical Correspondence Analysis describing the ballooning phenology of the 10 most abundant species over the 11 y of the study (see text for details). The explanatory variable is "year", indicated by its centroid (diamonds) in the ordination biplot. Grey circles describe the species in 2003; white circles are the means of the coordinates for the other years, with error bars indicating the $95 \%$ confidence intervals. The closed line joins the ballooning species in the extreme year 2003. Species codes: Ar: Agyneta rurestris; Ah: Araeoncus humilis; Ea: Erigone atra; Ed: E. dentipalpis; Mt: Mermessus trilobatus; Pa: Philodromus aureolus; Pr: Philodromus rufus; Pm: Porrhomma microphthalmum; Po: Porrhomma oblitum; Tt: Tenuiphantes tenuis.

Until 2002, "multimodal" and "unimodal" species separate into 2 groups, with strong similarities in their weekly abundances of captured individuals. This pattern disappears in the year 2003 .

\section{Discussion}

Our results reveal a clear difference in the population trends over the $11 \mathrm{y}$ of the study period according to habitat use: most ground-level species decreased, while most upper-strata species increased. Although this trend is partly driven by the Linyphiidae family, which is species rich and includes numerous ground dwellers, it appears to be specific to habitat use. The number of ballooning spiders is influenced by several interrelated factors, e.g., modification in the size of spider populations (e.g., Duffey, 1956), in flight motivation (Bonte, 2009; Bonte, Deblauwe \& Maelfait, 2003; Bonte et al., 2008; De Meester \& Bonte, 2010; Goodacre et al., 2009; Mestre \& Bonte, 2012), or in climatic conditions (Reynolds, Bohan \& Bell, 2007; Rensch, Volkmar \& Spilke, 2010). The observed difference in ballooning population trends between ground-level and upper-strata species could be due to several factors, the most plausible being a change in habitat availability 
and/or quality in open environments and different effects of climatic factors in open and closed habitats.

In our study area, the most noticeable change in landscape structure was the replacement of agricultural ecosystems by buildings and infrastructures, whilst the surface area of forest did not change (Bruggisser, 2010). This has induced a diminution of open-field ground-level spider populations at the landscape level, which probably contributed to the diminution of the number of ballooning individuals. This contrasts with the increase of captures of species inhabiting bushes and trees, habitats whose size did not change. However, the decrease in surface area of agricultural land amounted to only 3\% during the study period, compared to an $8 \%$ decrease in total ground-living spider abundance. Agricultural practices, particularly the use of pesticides, are known to affect spider populations (Thorbek \& Bilde, 2004). In our case, records of the quantity and composition of pesticides used are lacking, but there is no indication of major changes in agricultural practices during our study period (J. O. Derron, pers. comm.). Climatic effects are likely to contribute to the difference in trends between ground-level and upper-strata species, as the influence on the latter is attenuated by vegetation. During the study period, yearly averages of the different measures of temperature increased at the suction trap location, but not statistically significantly (Bruggisser, 2010); only global radiation showed a near-significant positive trend. Consequently, an effect of climate is likely, but the length of our time series is too short to provide clear evidence, and notably to disentangle the effects of habitat size and climate.

Except for the autumn peak of Erigone dentipalpis, the timing of peaks does not show any trend during the study period. In all, the ballooning phenology appears to be quite stable for the studied species. This contrasts with reports from other taxonomic groups (Parmesan \& Yohe, 2003; Root et al., 2003; Parmesan, 2007), which could be partly explained by the low metabolism rate of spiders (Brose et al., 2008; Rall et al., 2010; Foelix, 2011) making them less sensitive to climatic changes than other organisms. In line with this result, the timing of peaks is only weakly related to meteorological conditions in our study. Furthermore, responses to these parameters differ among species. The results for the summer peak are the most consistent, with peaks occurring earlier with higher temperatures for all species except Agyneta rurestris. It is interesting to note that the observed decreasing trends in ballooning population sizes for these ground-inhabiting species are not linked to changes in their phenology.

Our results also provide information on the different responses of ground-living versus upper-strata spiders to extreme climatic events. In 2003, the summer was unusually warm and dry and the autumn cold, conditions that are likely to become more frequent in central Europe in the future (Beniston, 2004; Coumou \& Rahmstorf, 2012). Ground-living spiders decreased markedly in 2003, and several factors concur to explain this observation. In our study, the Linyphiidae family, which is known to be susceptible to desiccation, represents $76 \%$ of all species in this group (Topping \& Sunderland, 1998; Kumschick et al., 2009). Additionally, it is possible that mortality increased due to reductions in the populations of important prey like Collembola (Agustí et al., 2003; Nyffeler \& Sunderland, 2003), which were shown by Aebischer (1991) to collapse during dry summers, and take 3 to 5 y to recover. Finally, the ballooning propensity and efficiency of spiders can decline with high temperatures (Reynolds, Bohan \& Bell, 2007; Bonte et al., 2008). In contrast, spiders living on upper strata did not decrease in 2003. Meteorological conditions are more buffered in upper strata than at ground level. It is thus possible that the dry and hot summer had a positive effect on the population dynamics of these spiders because of increased prey availability and good conditions for foraging (e.g., web construction). It is possible that the extreme climatic event of 2003 also resulted in the unusually low numbers of some ballooning species (Araeoncus humilis, Bathyphantes gracilis, Erigone atra, and Erigone dentipalpis) in 2004. Finally, it is interesting to note that this extreme event markedly changed the structure of the ballooning spider assemblage, which was very stable until 2002 (Figure 2). It is also worthwhile to note that the global phenology in 2004 (the 2004 diamond in Figure 2) went back to a situation similar to that prevailing between 1994 and 2002, indicating that the 2003 climatic event did not trigger a regime shift in ballooning spider phenology (Scheffer et al., 2001).

Understanding the factors underlying the population dynamics of spiders is particularly important because of their functional role as bio-control agents in agroecosystems (Nyffeler \& Sunderland, 2003). Our results reveal that the ballooning phenology of these species is only weakly affected by meteorological conditions, except in the case of extreme events. However, we also showed that groundliving species, which are important predators in agricultural systems, decreased during the study period. This negative trend can be attributed to some degree to climatic effects, as well as to habitat loss.

Contrary to several meta-analyses on phenology including arthropods (Parmesan \& Yohe, 2003; Root et al., 2003; Parmesan, 2007), we did not detect any change in the timing of ballooning peaks. In line with this observation, we found little relationship between the timing of peaks and meteorological conditions. These results highlight the need to place spiders under close scrutiny with regard to climate changes. We also revealed a clear difference in the population trends according to habitat use: most ground-level species decreased, while most upper-strata species increased. Management to improve habitat quality in agroecosystems could counteract this impoverishment (Haaland, Naisbit \& Bersier, 2011; Nentwig, 2000), e.g., manipulation of microhabitats (Alderweireldt, 1994; Marc, Canard \& Ysnel, 1999).

\section{Acknowledgements}

This study was funded by grants from the Centre Suisse de Cartographie de la Faune (CSCF), the University of Fribourg, and the Agroscope ACW Changins-Wädenswil research station and by the Swiss National Science Foundation (grant 31003A-138489). We thank J. Derron, G. Goy, and their colleagues at the Changins research station for giving us the opportunity to work on their arachnological material and for technical assistance. R. Charles 
gave us access to the archives of agricultural management of the ACW Changins area. M.-F. Cattin and R. Naisbit made useful comments on the manuscript.

\section{Literature cited}

Aebischer, N. J., 1991. Twenty years of monitoring invertebrates and weeds in cereal fields in Sussex. Pages 305-331 in L. G. Firbank, N. Carter, J. F. Dabyshire \& G. R. Potts (eds). The Ecology of Temperate Cereal Fields. 32 ${ }^{\text {nd }}$ Symposium of the British Ecological Society. Blackwell Scientific Publications, Oxford.

Agustí, N., S. P. Shayler, J. D. Harwood, I. P. Vaughan, K. D. Sunderland \& W. O. C. Symondson, 2003. Collembola as alternative prey sustaining spiders in arable ecosystems: Prey detection within predators using molecular markers. Molecular Ecology, 12: 3467-3475.

Alderweireldt, M., 1994. Habitat manipulations increasing spider densities in agroecosystems: Possibilities for biological control? Journal of Applied Entomology, 118: 10-16.

Bell, J. R., D. A. Bohan, E. M. Shaw \& G. S. Weyman, 2005. Ballooning dispersal using silk: World fauna, phylogenies, genetics and models. Bulletin of Entomological Research, 95: 69-114.

Beniston, M., 2004. The 2003 heat wave in Europe: A shape of things to come? An analysis based on Swiss climatological data and model simulations. Geophysical Research Letters, 31: 2022-2026.

Birkhofer, K. \& V. Wolters, 2012. The global relationship between climate, net primary production and the diet of spiders. Global Ecology and Biogeography, 21: 100-108.

Blandenier, G., 2009. Ballooning of spiders (Araneae) in Switzerland: General results from an eleven-years survey. Bulletin of the British Arachnological Society, 14: 308-316.

Blandenier, G., O. T. Bruggiser, P. R. Rohr \& L.-F. Bersier, 2013. Are phenological patterns of ballooning spiders linked to habitat characteristics? Journal of Arachnology, 41: 126-132.

Bonte, D., 2009. Inbreeding depresses short and long distance dispersal in three congeneric spiders. Journal of Evolutionary Biology, 22: 1429-1434.

Bonte, D., I. Deblauwe \& J.-P. Maelfait, 2003. Environmental and genetic background of tiptoe-initiating behaviour in the dwarfspider Erigone atra. Animal Behaviour, 66: 169-174. Doi: 10.1006/anbe.2003.2191

Bonte, D., T. Hovestadt \& H. J. Poethke, 2010. Evolution of dispersal polymorphism and local adaptation of dispersal distance in spatially structured landscapes. Oikos, 119: 560-566. Doi: 10.1111/j.1600-0706.2009.17943.x

Bonte, D., N. Vandenbroecke, L. Lens \& J.-P. Maelfait, 2003. Low propensity for aerial dispersal in specialist spider from fragmented landscapes. Proceedings of the Royal Society of London B, 270: 1601-1607. Doi: 10.1098/rspb.2003.2432

Bonte, D., J. Vanden Borre, L. Lens \& J.-P. Maelfait, 2006. Geographical variation in wolf spider dispersal behaviour is related to landscape structure. Animal behaviour, 72: 655-662.

Bonte, D., J. M. J. Travis, N. De Clercq, I. Zwertvaegher \& L. Lens, 2008. Thermal conditions during juvenile development affect adult dispersal in a spider. Proceedings of the National Academy of Sciences of the United States of America, 105: 17000-17005.

Borcard, D., F. Gillet \& P. Legendre, 2011. Numerical Ecology with R. Springer, New York, New York.
Brose, U., R. B. Ehnes, B. C. Rall, O. Vucic-Pestic, E. L. Berlow \& S. Scheu, 2008. Foraging theory predicts predator-prey energy fluxes. Journal of Animal Ecology, 77: 1072-1078.

Bruggisser, O. T., 2010. Understanding the structure of interactions and the dynamics of spider populations in agricultural ecosystems. PhD thesis. University of Fribourg, Fribourg.

CH2011, 2011. Swiss Climate Change Scenarios CH2011. C2SM, Meteoswiss, ETH, NCCR Climate, and ocCC, Zurich.

Coumou, D. \& S. Rahmstorf, 2012. A decade of weather extremes. Nature Climate Change, 2: 491-496.

De Meester, N. \& D. Bonte, 2010. Information use and densitydependent emigration in an agrobiont spider. Behavioral Ecology, 21: 992-998.

Derron, J. O. \& G. Goy, 1987. Utilisation des pièges à aspiration pour la prévision des épidémies de virus. Revue Suisse d'Agriculture, 19: 129-132.

Duffey, E., 1956. Aerial dispersal in a known spider population. Journal of Animal Ecology, 25: 85-111.

Entling, M. H., K. Stämpfli \& O. Ovaskainen, 2011. Increased propensity for aerial dispersal in disturbed habitats due to intraspecific variation and species turnover. Oikos, 120: 1099-1109.

Foelix, R., 2011. Biology of Spiders. Oxford University Press, Oxford.

Good, I. J. \& R. A. Gaskins, 1980. Density estimation and bumphunting by the penalized likelihood method exemplified by scattering and meteorite data. Journal of the American Statistical Association, 75: 42-56.

Goodacre, S. L., O. Y. Martin, D. Bonte, L. Hutchings, C. Woolley, K. Ibrahim, C. F. G. Thomas, \& G. M. Hewitt, 2009. Microbial modification of host long-distance dispersal capacity. BMC Biology, 7: 32.

Haaland, C., R. Naisbit \& L.-F. Bersier, 2011. Sown wildflower strips for insect conservation: A review. Insect Conservation and Diversity, 4: 60-80.

Hänggi, A., E. Stöckli \& W. Nentwig, 1995. Habitats of Central European Spiders. Centre Suisse de Cartographie de la Faune (CSCF), Neuchâtel.

Heimer, S. \& W. Nentwig, 1991. Spinnen Mitteleuropas. Verlag Paul Parey, Berlin und Hamburg.

Høye, T. T. \& M. C. Forchhammer, 2008. Phenology of higharctic arthropods: Effects of climate on spatial, seasonal, and inter-annual variation. Advances in Ecological Research, 40: 299-324. Doi: 10.1016/S0065-2504(07)00013-X

Jaksić, F. M. \& R. G. Medel, 1990. Objective recognition of guilds: Testing for statistically significant species clusters. Oecologia, 82: 87-92.

Kumschick, S., M. H. Schmidt-Entling, S. Bacher, T. Hickler, W. Entling \& W. Nentwig, 2009. Water limitation prevails over energy in European diversity gradients of sheetweb spiders (Araneae: Linyphiidae). Basic and Applied Ecology, 10: 754-762.

Legendre, R. \& L. Legendre, 1998. Numerical Ecology. Elsevier, Amsterdam.

Marc, P., A. Canard \& F. Ysnel, 1999. Spiders (Araneae) useful for pest limitation and bioindication. Agriculture Ecosystems \& Environment, 74: 229-273.

Mestre, L. \& D. Bonte, 2012. Food stress during juvenile and maternal development shapes natal and breeding dispersal in a spider. Behavioural Ecology, 23: 759-764.

Nentwig, W., 2000. Streifenförmige ökologische Ausgleichsflächen in der Kulturlandschaft. Ackerkrautstreifen, Buntbrache, Feldränder. Verlag Agrarökologie, Berne, Hannover. 
Nentwig, W., T. Blick, D. Gloor, A. Hänggi \& C. Kropf, 2010. Spiders of Europe. Online [URL] http://www.araneae.unibe.ch (Accessed on 10 January 2010).

Neuheimer, A. B. \& C. T. Taggart, 2007. The growing degree-day and fish size-at-age: The overlooked metric. Canadian Journal of Fisheries and Aquatic Sciences, 64: 375-385.

Nyffeler, M. \& K. D. Sunderland, 2003. Composition, abundance and pest control potential of spider communities in agroecosystems: A comparison of European and US studies. Agriculture, Ecosystems and Environment, 95: 579-612.

Oksanen, J., R. Kindt, P. Legendre, R. B. O'Hara, G. L. Simpson, P. Solymos, H. Stevens \& H. Wagner, 2009. Vegan: Community Ecology Package. R package version 1.15-3.

Parmesan, C., 2007. Influences of species, latitudes and methodologies on estimates of phenological response to global warming. Global Change Biology, 13: 1860-1872.

Parmesan, C. \& G. Yohe, 2003. A globally coherent fingerprint of climate change impacts across natural systems. Nature, 421: $37-42$.

Platnick, N. I., 2013. The World Spider Catalog. Version 14.0. American Museum of Natural History. Online [URL] http:// research.amnh.org/entomology/spiders/catalog. (Accessed on 1 July 2013)

R Development Core Team, 2009. R: A Language and Environment for Statistical Computing. R Foundation for Statistical Computing, Vienna. Online [URL] http://www.Rproject.org (Accessed on 8 November 2009)

Rall, B. C., O. Vucic-Pestic, R. B. Ehnes, M. Emmerson \& U. Brose, 2010. Temperature, predator-prey interaction strength and population stability. Global Change Biology, 16: $2145-2157$.
Rensch, M., C. Volkmar \& J. Spilke, 2010. Aerial dispersal of spiders in central east Germany: Modelling of meteorological and seasonal parameters. Pages 147-152 in W. Nentwig, M. Entling \& C. Kropf (eds). Proceedings of the $24^{\text {th }}$ European Colloquium of Arachnology, Bern 2008.

Reynolds, A. M., D. A. Bohan \& J. R. Bell, 2007. Ballooning dispersal in arthropod taxa: Conditions at take-off. Biology Letters, 3: 237-240.

Roberts, M. J., 1993. The Spiders of Great Britain and Ireland. Harley Books, Colchester.

Root, T. L., J. T. Price, K. R. Hall, S. H. Schneider, C. Rosenzweig $\&$ J. A. Pounds, 2003. Fingerprints of global warming on wild animals and plants. Nature, 421: 57-60.

Scheffer, M., S. Carpenter, J. Foley, C. Folke \& B. Walker, 2001. Catastrophic shifts in ecosystems. Nature, 413: 591-596.

Silverman, B. W., 1981. Using kernel density estimates to investigate multimodality. Journal of the Royal Statistical Society Series B (Methodological), 43: 97-99.

Sokal, R. R. \& F. J. Rohlf, 2000. Biometry. Freeman and Company, New York, New York.

Szymkowiak, P., G. Górski \& D. Bajerlein, 2007. Passive dispersal in arachnids. Biological Letters, 44: 75-101.

Taylor, L. R. \& J. P. Palmer, 1972. Aerial sampling. Pages 189-234 in H. F. Van Emdem (ed.). Aphid Technology. Academic Press, London.

Thorbek, P. \& T. Bilde, 2004. Reduced numbers of generalist arthropod predators after crop management. Journal of Applied Ecology, 41: 526-538.

Topping, C. J. \& K. D. Sunderland, 1998. Population dynamics and dispersal of Lepthyphantes tenuis in an ephemeral habitat. Entomologia Experimentalis et Applicata, 87: 29-41. 


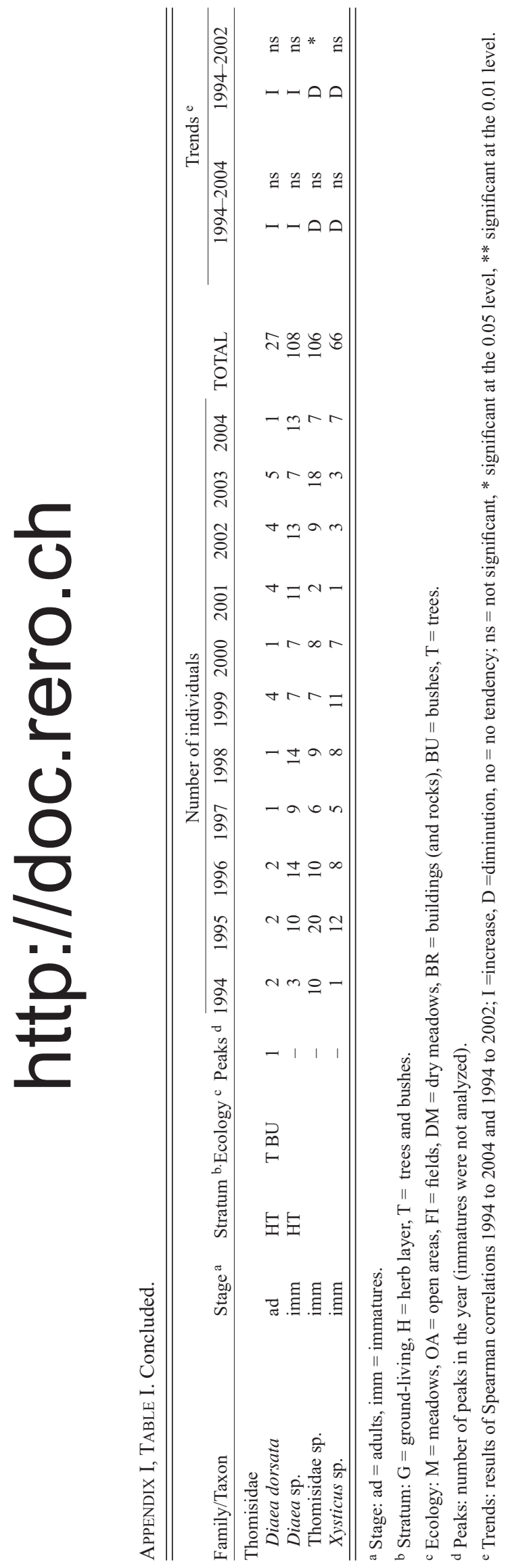




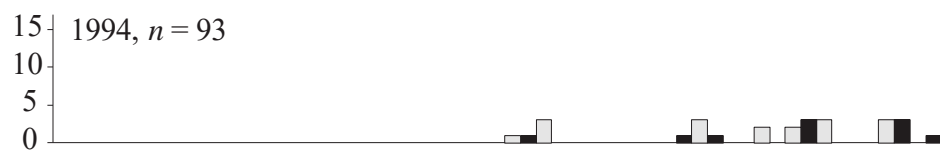

15- $1995, n=83$

10.

5 -

0

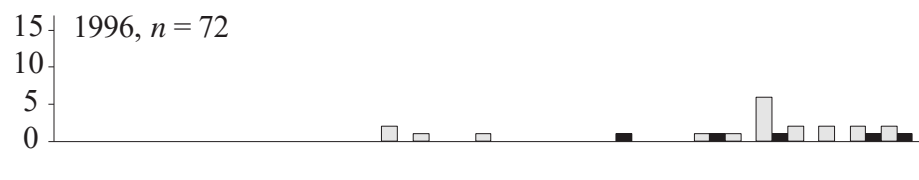

A.I.
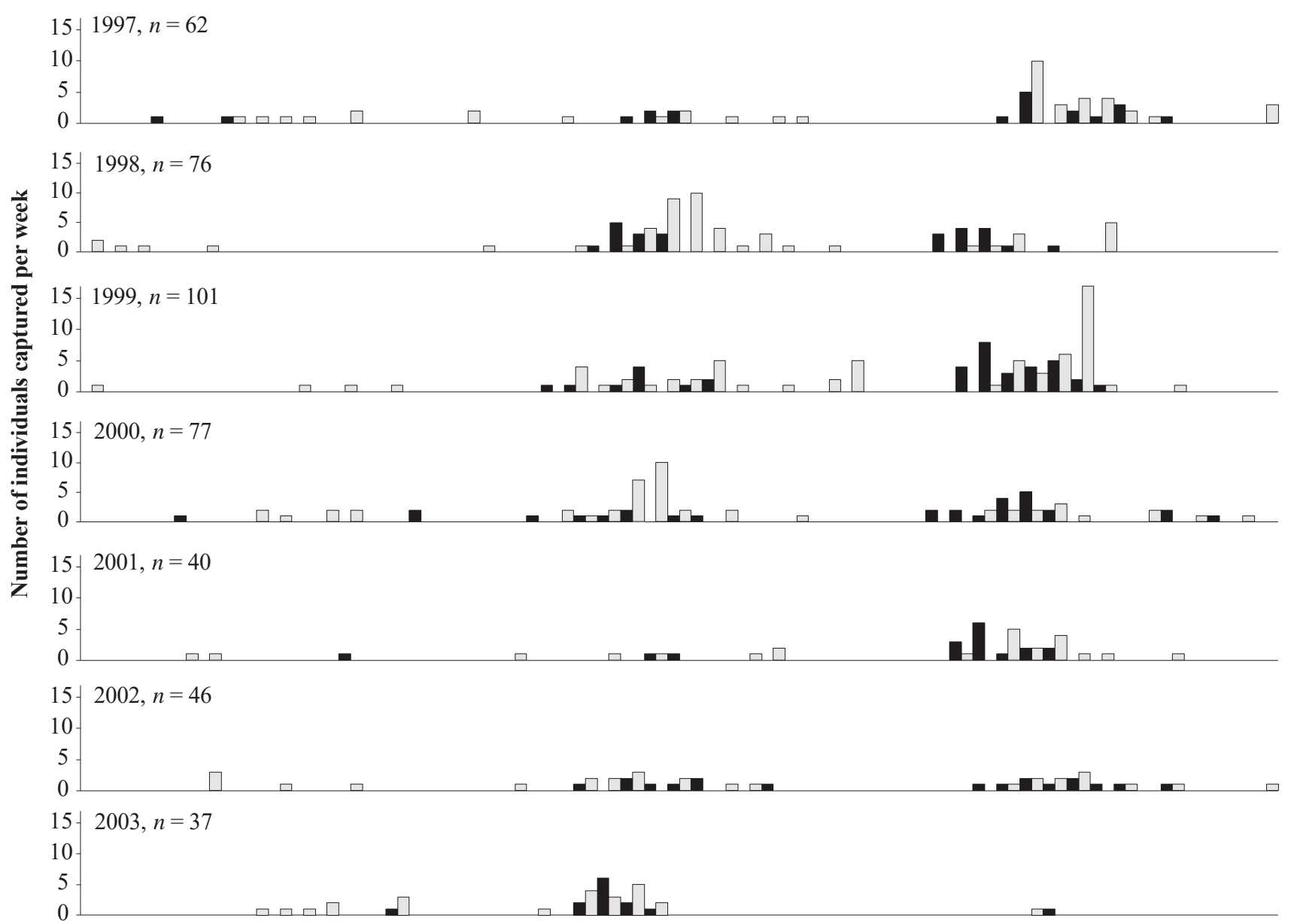

15- $2004, n=19$

10

5

0

40 Total, $n=706$

30

20 -

10

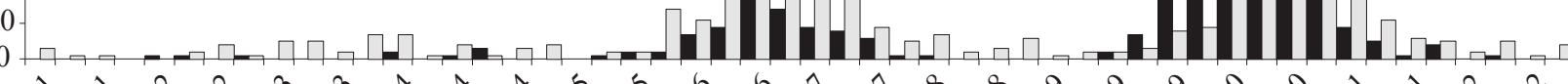

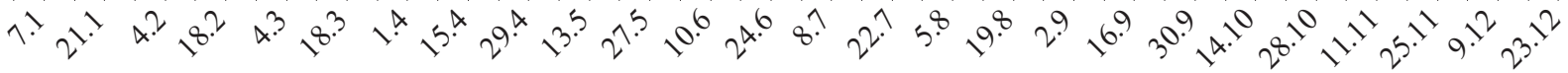

Day, month

APPENDIX I, FIgURE 1. Weekly captures of Araeoncus humilis, an example for which numbers significantly decreased. Black: males; light grey: females. Note the dramatic reduction in late 2003 and 2004. 
10
8
6
4
2
0

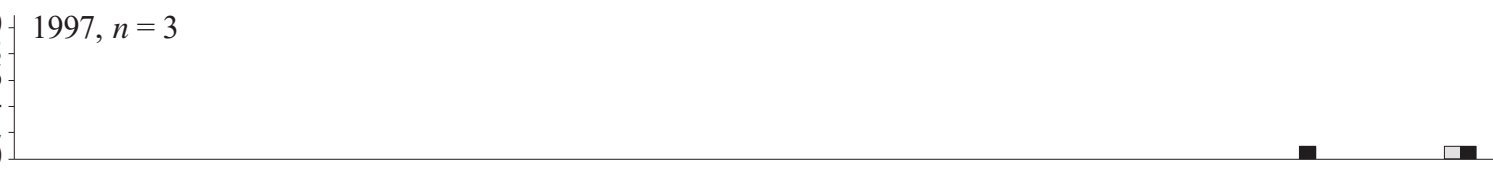

$10+1998, n=7$

6

2
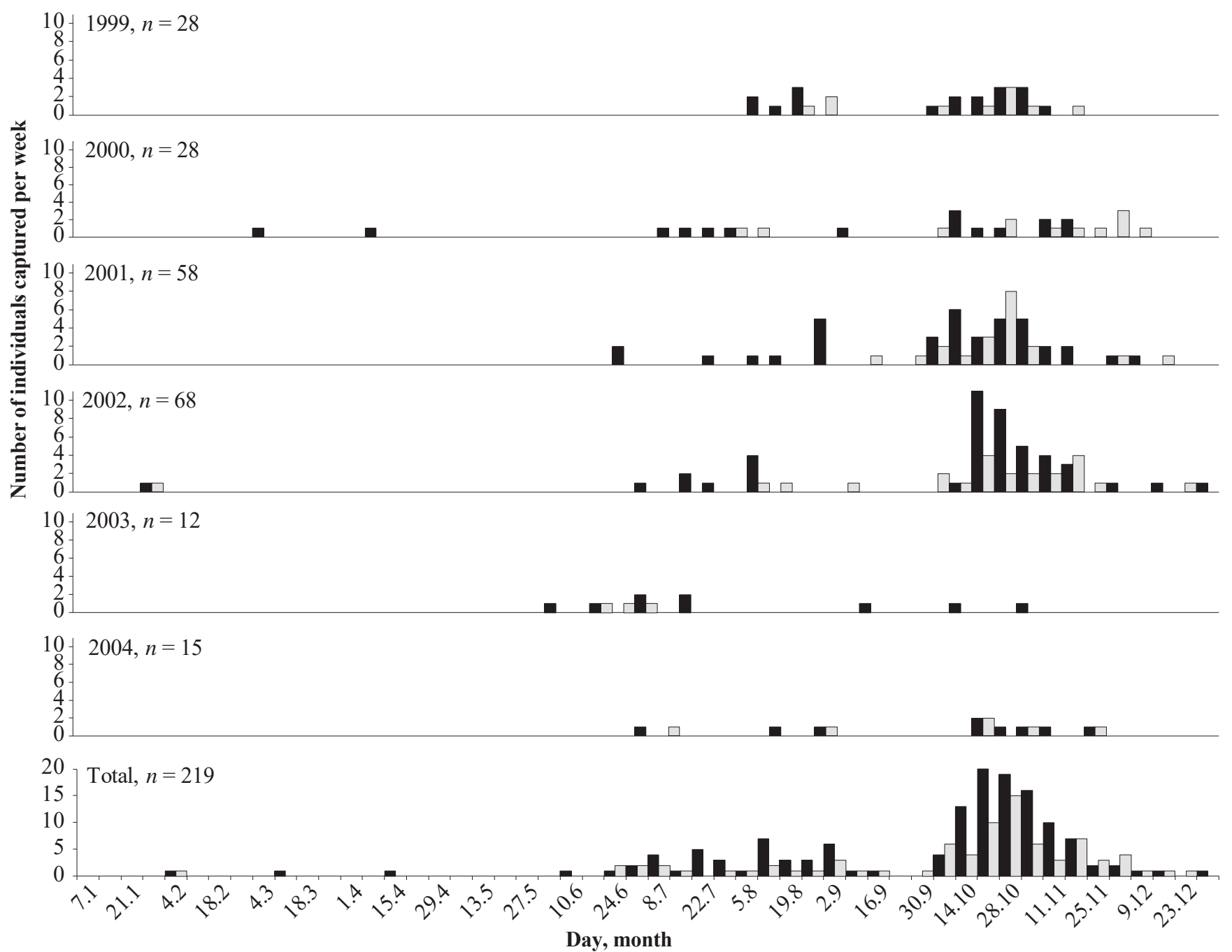

ApPendix I, FiguRE 2. Weekly captures of Mermessus trilobatus, an example for which numbers significantly increased. Black: males; light grey: females. Note the dramatic reduction in late 2003 and 2004. 
APPENDIX I, TABLE II. Spearman correlations between the dates of each peak and the meteorological parameters considered 1 month before the peak. All peaks: all peaks considered together. Boldface and italic types: Spearman correlations with $P \leq 0.05$ and $0.05<P \leq 0.1$, respectively.

\begin{tabular}{|c|c|c|c|c|c|c|c|c|}
\hline \multirow[b]{2}{*}{ Species } & \multicolumn{2}{|c|}{ All peaks } & \multicolumn{2}{|c|}{ Late winter/spring } & \multicolumn{2}{|c|}{ Summer } & \multicolumn{2}{|c|}{ Autumn } \\
\hline & Coefficient & $P$ & Coefficient & $P$ & Coefficient & $P$ & Coefficient & $P$ \\
\hline \multicolumn{9}{|l|}{ Average temperature $\left({ }^{\circ} \mathrm{C}\right)$} \\
\hline Araeoncus humilis & -0.326 & 0.064 & -0.296 & 0.377 & -0.786 & 0.004 & 0.093 & 0.786 \\
\hline Erigone atra & 0.102 & 0.606 & -0.154 & 0.715 & -0.126 & 0.713 & 0.861 & 0.003 \\
\hline Erigone dentipalpis & -0.487 & 0.055 & & & -0.653 & 0.056 & -0.106 & 0.820 \\
\hline Agyneta rurestris & 0.057 & 0.757 & 0.096 & 0.780 & 0.089 & 0.795 & -0.080 & 0.826 \\
\hline Porrhomma microphthalmum & 0.025 & 0.900 & 0.444 & 0.270 & -0.162 & 0.634 & -0.248 & 0.520 \\
\hline Tenuiphantes tenuis & 0.147 & 0.573 & & & -0.278 & 0.468 & 0.735 & 0.038 \\
\hline \multicolumn{9}{|l|}{ Minimal temperature $\left({ }^{\circ} \mathrm{C}\right)$} \\
\hline Araeoncus humilis & -0.339 & 0.054 & -0.398 & 0.226 & -0.821 & 0.002 & 0.133 & 0.698 \\
\hline Erigone atra & 0.165 & 0.400 & -0.124 & 0.770 & -0.043 & 0.900 & 0.757 & 0.018 \\
\hline Erigone dentipalpis & -0.527 & 0.036 & & & -0.620 & 0.075 & -0.377 & 0.405 \\
\hline Agyneta rurestris & 0.132 & 0.473 & 0.153 & 0.653 & 0.248 & 0.463 & -0.034 & 0.925 \\
\hline Mermessus trilobatus & -0.049 & 0.867 & & & -0.331 & 0.522 & 0.234 & 0.576 \\
\hline Tenuiphantes tenuis & -0.004 & 0.987 & & & -0.293 & 0.443 & 0.510 & 0.196 \\
\hline \multicolumn{9}{|l|}{ Maximal temperature $\left({ }^{\circ} \mathrm{C}\right)$} \\
\hline Araeoncus humilis & -0.302 & 0.088 & -0.243 & 0.471 & -0.815 & 0.002 & 0.127 & 0.710 \\
\hline Erigone atra & 0.097 & 0.623 & -0.295 & 0.478 & -0.144 & 0.673 & 0.879 & 0.002 \\
\hline Erigone dentipalpis & -0.482 & 0.059 & & & -0.611 & 0.081 & -0.194 & 0.676 \\
\hline Agyneta rurestris & 0.005 & 0.980 & -0.028 & 0.936 & 0.087 & 0.800 & -0.109 & 0.765 \\
\hline Mermessus trilobatus & -0.130 & 0.659 & & & -0.561 & 0.247 & 0.357 & 0.385 \\
\hline Porrhomma microphthalmum & 0.086 & 0.663 & 0.529 & 0.177 & -0.140 & 0.682 & -0.132 & 0.736 \\
\hline Tenuiphantes tenuis & 0.185 & 0.478 & & & -0.213 & 0.581 & 0.723 & 0.043 \\
\hline \multicolumn{9}{|c|}{ Minimal temperature $5 \mathrm{~cm}$ above ground $\left({ }^{\circ} \mathrm{C}\right)$} \\
\hline Araeoncus humilis & -0.309 & 0.081 & -0.309 & 0.355 & -0.798 & 0.003 & 0.077 & 0.822 \\
\hline Erigone atra & 0.078 & 0.693 & -0.178 & 0.674 & -0.079 & 0.818 & 0.574 & 0.106 \\
\hline Erigone dentipalpis & -0.364 & 0.166 & & & -0.331 & 0.384 & -0.463 & 0.295 \\
\hline Agyneta rurestris & 0.174 & 0.340 & 0.180 & 0.596 & 0.282 & 0.401 & 0.041 & 0.911 \\
\hline Mermessus trilobatus & -0.057 & 0.846 & & & -0.271 & 0.603 & 0.125 & 0.768 \\
\hline Porrhomma microphthalmum & -0.113 & 0.566 & 0.251 & 0.548 & -0.327 & 0.327 & -0.296 & 0.440 \\
\hline Araeoncus humilis & 0.053 & 0.770 & -0.195 & 0.565 & 0.732 & 0.010 & -0.299 & 0.371 \\
\hline Erigone atra & 0.343 & 0.074 & 0.412 & 0.310 & 0.409 & 0.212 & 0.290 & 0.448 \\
\hline Erigone dentipalpis & 0.076 & 0.778 & & & 0.252 & 0.513 & -0.257 & 0.578 \\
\hline Agyneta rurestris & 0.205 & 0.260 & 0.085 & 0.804 & 0.342 & 0.304 & 0.250 & 0.486 \\
\hline Mermessus trilobatus & 0.205 & 0.481 & & & 0.761 & 0.079 & -0.331 & 0.424 \\
\hline Porrhomma microphthalmum & -0.123 & 0.534 & -0.695 & 0.056 & 0.345 & 0.298 & -0.264 & 0.493 \\
\hline Tenuiphantes tenuis & 0.002 & 0.995 & & & 0.374 & 0.322 & -0.505 & 0.202 \\
\hline \multicolumn{9}{|l|}{ Global radiation $\left(\mathrm{MJ} \cdot \mathrm{m}^{2}\right)$} \\
\hline Araeoncus humilis & -0.105 & 0.561 & 0.475 & 0.140 & -0.806 & 0.003 & 0.015 & 0.964 \\
\hline Erigone atra & -0.004 & 0.986 & -0.536 & 0.171 & -0.183 & 0.590 & 0.567 & 0.111 \\
\hline Erigone dentipalpis & -0.380 & 0.147 & & & -0.456 & 0.217 & -0.212 & 0.649 \\
\hline Agyneta rurestris & -0.190 & 0.298 & 0.094 & 0.783 & -0.297 & 0.374 & -0.450 & 0.192 \\
\hline Mermessus trilobatus & 0.153 & 0.601 & & & 0.323 & 0.533 & -0.015 & 0.971 \\
\hline Porrhomma microphthalmum & 0.201 & 0.305 & 0.659 & 0.075 & -0.263 & 0.434 & 0.446 & 0.228 \\
\hline Tenuiphantes tenuis & 0.164 & 0.529 & & & -0.205 & 0.596 & 0.618 & 0.102 \\
\hline
\end{tabular}




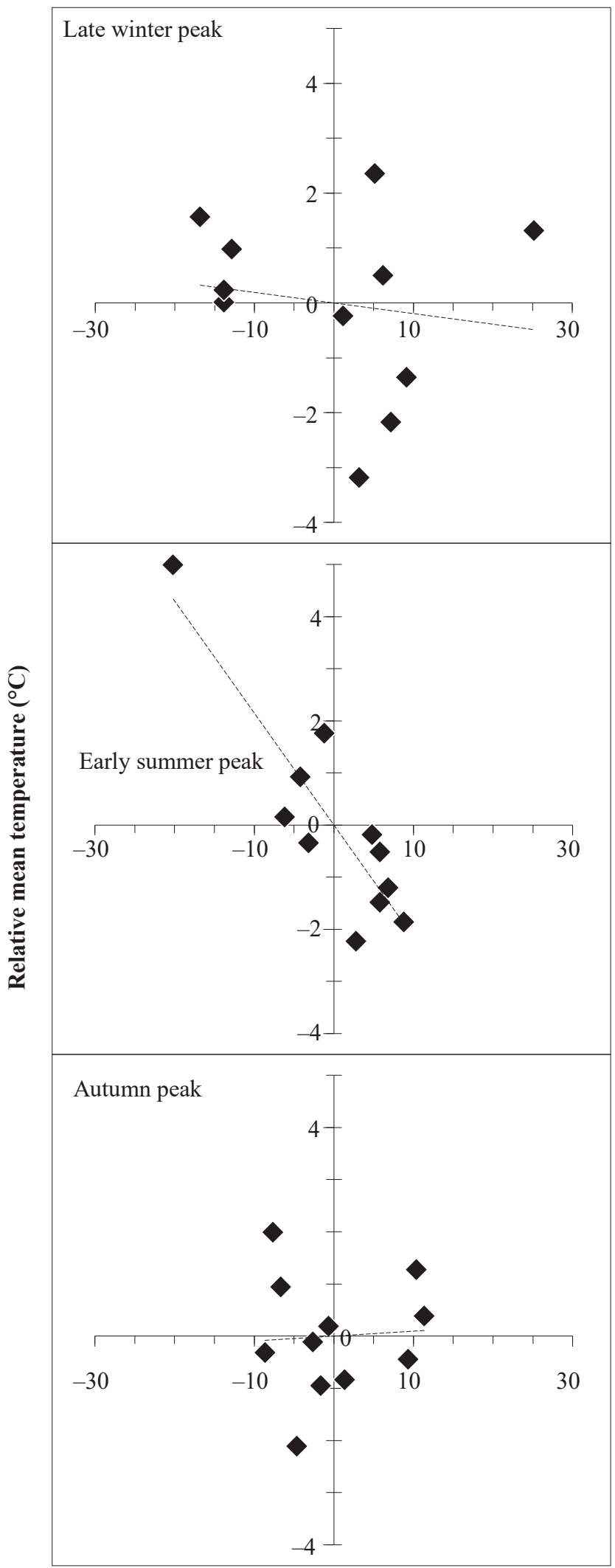

Relative peak date (day)

APPENDIX I, FIGURE 3. Correlation between the date of ballooning peaks in Araeoncus humilis and the mean temperature during the month before the peak. Dates and temperatures are centred on their overall mean for the 11 y (for the 3 peaks, mean peak dates are March $16^{\text {th }}$. June $30^{\text {th }}$, and October $26^{\text {th }}$ and mean temperatures are $4.9,18.0$, and $11.7^{\circ} \mathrm{C}$, respectively). Dashed lines represent linear regressions (for the 3 peaks, $R^{2}$ are $0.02,0.78$, and 0.004 , respectively; see Appendix I, Table II for Spearman correlation tests). 

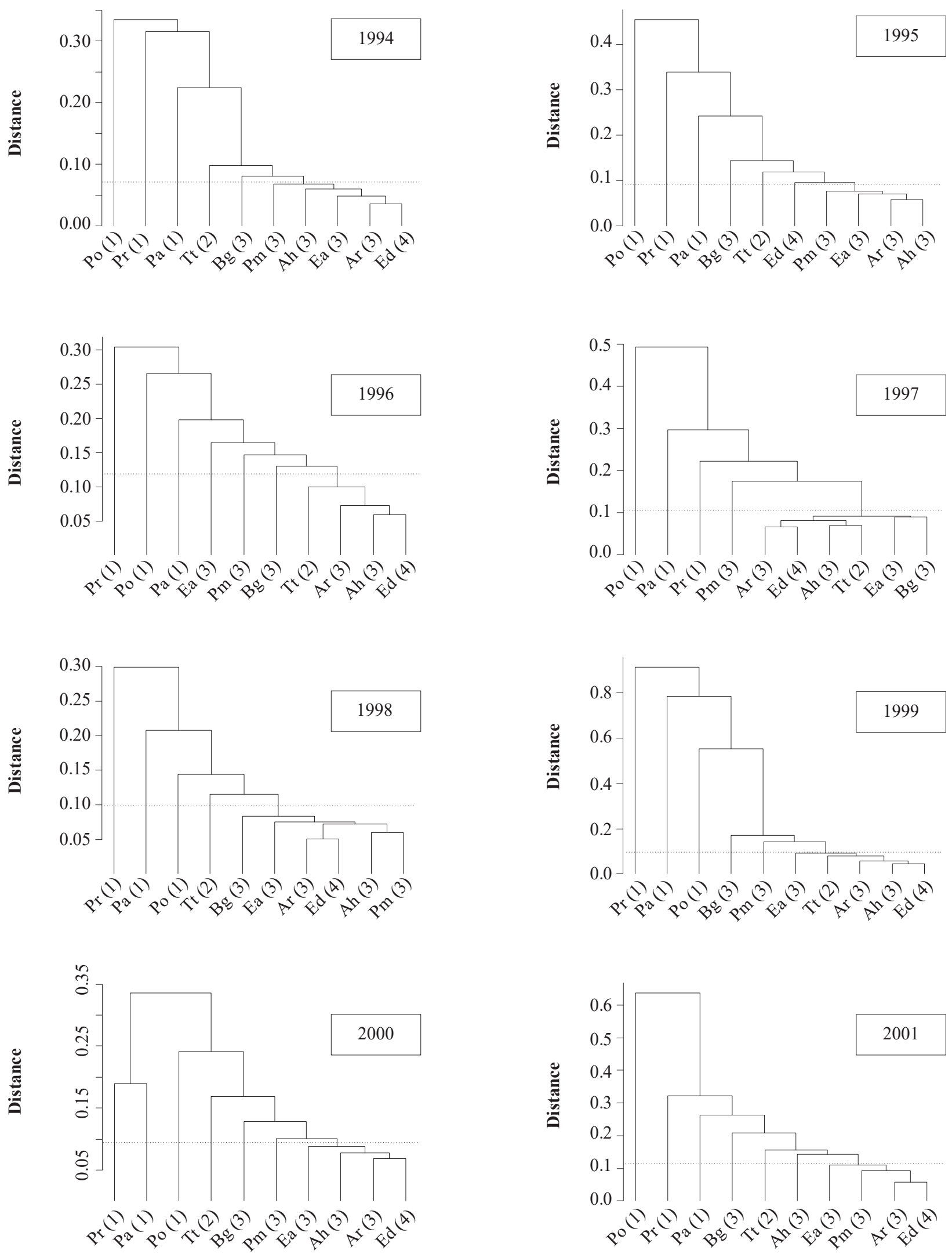

ApPendix I, Figure 4. Changes in the phenological groups among the 10 most abundant species captured every year over the period $1994-2004$. Complete linkage agglomerative clustering. Dotted line: significant group recognition at $P=0.05$ (Jaksić \& Medel, 1990). Species codes (in parentheses: number of ballooning peaks): Ar: Agyneta rurestris; Ah: Araeoncus humilis; Bg: Bathyphantes gracilis; Ea: Erigone atra; Ed: Erigone dentipalpis; Pa: Philodromus aureolus; Pr: Philodromus rufus; Pm: Porrhomma microphthalmum; Po: Porrhomma oblitum; Tt: Tenuiphantes tenuis. 

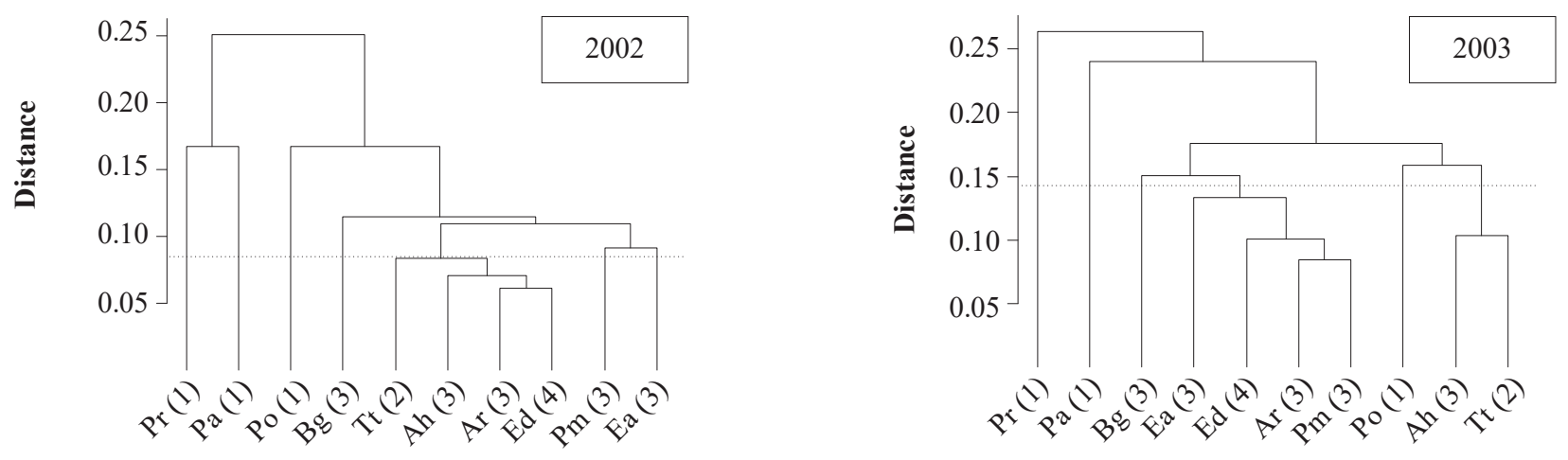

$\frac{1}{0}$

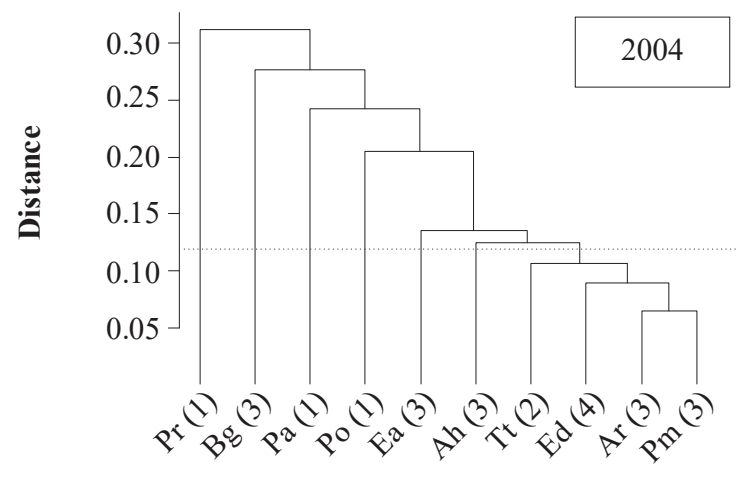

ApPendix I, Figure 4. Concluded.

응

邹 